\title{
Cooperation, not confrontation
}

It is not new to hear James Grant, the Director of UNICEF, propound the principles of GOBI at an international conference: Growth monitoring, Oral rehydration, Breast feeding, and Immunisation are the four key components of the 'child survival revolution', which is beginning to reduce child mortality in some developing countries. ${ }^{1}$ Nor is it new to hear Dr Ralph Henderson, the Director of the World Health Organisation Expanded Programme of Immunisation, assert that measles and poliomyelitis could be eradicated from the world as smallpox was, even though at present only $15 \%$ of the world's children receive protection against measles. Yet the recent conference held in Budapest was different because it was attended both by physicians and by politicians who feel that the child survival revolution will never happen unless the arms race is drastically curtailed.

This year the world's children were at the centre of the discussions at the 5th Congress of International Physicians for the Prevention of Nuclear War-an international pressure group of doctors which was started in 1980 by an American and a Russian cardiologist who felt that their patients were more at risk from nuclear weapons than from heart attacks. 'But that's political' is a frequently heard protest about the nature of such work. However, as several speakers pointed out, health is political: doctors who condemned child labour in the last century were told it was 'none of their business as physicians'.

However, it may justifiably be asked what has the arms race got to do with children. The conference pointed to three ways.

First, in the event of a nuclear war, that will be the end for children. Spreading information on the medical effects of nuclear war has been the main task of International Physicians for the Prevention of Nuclear War (and its United Kingdom affiliate, the Medical Campaign against Nuclear Weapons). Most doctors will now be aware of the British Medical Association report on this subject and of the newer data on the 'nuclear winter', which would affect the survival of populations far outside the actual conflict zone.

Second, heavy arms spending severely curtails the amount of money left for the health budget. Victor Seidel of the American Public Health Association provided many dramatic cost comparisons: for instance, that every two seconds one child dies and another is handicapped by a preventable disease while $\$ 25000$ is spent on arms; that 200 million doses of vaccine could be bought for the cost of a single military 'plane. These 'coulds' serve to draw attention to the awfulness of the arms race but become numbing after repetition, and, anyway, how can we be sure that the money would be spent that way? The main purpose of such comparisons is to highlight the size of many countries' obscenely huge military budgets. Closer comparisons have been made by epidemiologists of military spending and child mortality. ${ }^{2}$ Dr Ian Munro, the
Editor of the Lancet, who was present at the congress, felt that the publication of such papers was an important way for medical journals to take account of such issues, though he noted the attack such a paper in his journal later received. ${ }^{3}$

It was pointed out that it is not just military budgets which curtail effective action against preventable child deaths but the cold war itself-by reducing the potential for international medical collaboration. $\mathrm{Dr}$ Halfdan Mahler, the Director General of WHO, appealed to health workers to press their governments to cooperate over world health issues, pointing out that smallpox was eradicated (at a cost of three hours of world arms spending) by a team which included American and Russian doctors-many of whom were present in Budapest.

These issues may be regarded as of little importance to the busy paediatrician and his child patients. However, we should all recognise the third way in which nuclear weapons affect children: by their psychological impact. A workshop at the Budapest conference discussed the recent findings that children in several countries view nuclear war as the greatest threat to their future. ${ }^{45}$ Those who suggest that this fear has been improperly implanted in their minds may be burying their heads in the sand.

The final recommendation of the meeting was undoubtedly political, but many speakers, including Sir Raymond Hoffenburg (President of the Royal College of Physicians of London) and Dr Stephen Lock (Editor of the British Medical Journal), drew parallels with other public health issues, such as cholera and cigarette smoking, where long drawn out campaigns by doctors on the political aspects have eventually been successful. The main proposals made at the end were for a comprehensive test ban treaty, for the strengthening of the nuclear non-proliferation treaty, and for joint efforts by physicians in East and West to improve the health of the world's children. Perhaps paediatricians throughout the world could support all of these; 'The health of Americans depends on the Soviet Union, the health of Russians depends on the United States, the health of all the world depends on both nations'.

TONY WaTERSTON

Department of Child Health, Dundee

\section{References}

1 Grant JP. State of the world's children 1985. Oxford: Oxford University Press, 1984.

2 Woolhandler S, Himmelstein DU. Militarism and mortality. Lancet 1985;i:1375-8.

${ }^{3}$ Skrabanek P. Militarism and mortality. Lancet 1985;ii:46.

4 Solantaus T, Rimpela M. Taipale V. The threat of war in the minds of 12-18 year-olds in Finland. Lancet 1984;i:784-5.

${ }^{5}$ Barton $M$. Threat of war in the minds of children. Lancet 1985;i:226. 